\title{
BUILDING INFORMATION MODELS AS A BASIS OF PROCESS AUTOMATION DURING CONSTRUCTION AND OPERATION OF BUILDINGS AND STRUCTURES
}

\section{Hryhorovskyi P. Ye.}

\section{INTRODUCTION}

Methods of engineering, process mechanization and automation, project organization and management are interrelated and geared at a common objective - to shorten periods and ensure quality of construction, to prolong life cycles of construction projects by applying engineering and technical solutions on automatic control of processes with the use of construction information models and technologies, data obtained by instrumental measurements at all life cycle stages. Designing of integrated models and methods of automated systems for diagnostics of building operating conditions is an initial stage of development of a complex automated system that ensures serviceability of buildings. Components for instrumental measurements and program processing of data are integral parts of the automated system. Therefore measurements and software are the basic elements for automation of engineering processes at all stages of life cycle of buildings.

\section{Procedure of selection of information technologies for estimation of serviceability of buildings during their life cycles}

The building life cycle is subdivided into stages of survey, design work, preparation work, earthwork, construction of above-ground structures, operation and period of deterioration. The last stage may finalize the life cycle by means of liquidation or starting a new life cycle under the condition of reconstruction, overhaul or technical re-equipment that is by renewal of building operating conditions ${ }^{1}$. The life cycle interval is an important integral quality characteristic of building construction and operation. It depends on timely detection, correction and prediction of development of defects and damages which are impossible without acquisition and program processing of objective data on serviceability of buildings. Data

\footnotetext{
${ }^{1}$ Havryliak A.I. Operation, reconstruction and modernization of buildings / A. I. Havryliak, I. B. Bazarnyk, R. I. Kinash et al. - L'viv: Publisher National University «L'vivska politekhnika», 2006. -537 p. (in Ukrainian).
} 
objectiveness is ensured by instrumental methods of measurements. Generally, the up-to-date technologies and technical facilities comply with technological, regulatory and project requirements for quality during construction and operation of buildings.

Methods of execution of work, interrelations and interference of measurement and construction work affect efficiency of technological solutions, technical and economic indices of work performance, quality of work and duration of life cycles of projects. At the stage of construction the list and scope of measurements and work quality checks depend on applied technologies and materials, architectural and structural designs, conditions of construction. Jobs on construction of buildings with identical space and planning parameters but different structural or organizational and technological solutions have various scope and sequences of construction and measuring operations and this affects technical and economic indices of processes. Therefore, the technical and economic indices of measuring jobs at the construction and operation stages with identical scopes of jobs depend on organizational and technological as well as architectural and structural solutions.

Buildings differ in levels of complexity and uncertainty of their operating conditions, the number of factors that affect the processes of construction and operation, result in their deterioration, occurrence of deformations, defects and damages, therefore the required volume of data, methods of their processing, information models, methods and measures for execution of jobs directed on prolongation of life cycles of buildings depend on their structural features and technologies used for their construction and operation. Information about quality of a new construction project, defects and damages of facilities under operation shall be presented as a hard copy or in electronic format, as-built surveys, quality control data, defect charts or lists, inspection reports etc. Determination of interdependence of defects and causes of their occurrence, prediction of effects of these defects on future operating conditions of facilities is an important complex task that requires detailed studies with the use of up-to-day methods of information simulation.

Works of leading scientists show that the process of determination of parameters of buildings, structures or developed areas is under impact of destabilizing factors on technical and economic indices and accompanied by a set of specific features. In general these aspects are characterized by as follows:

- increased demands for growth in volumes and efficiency of construction of civil and industrial facilities, reconstruction and overhaul of facilities under operation; 
- shortened periods of construction and increased periods of operation of facilities due to application of new technologies, designs, equipment and materials;

- increased social role of safety and decreased levels of risks of facility wrecks due to ensured quality and reliability of construction and operation processes;

- complex studies of properties of buildings, simulation of their behavior under operating and dense development conditions before construction is started;

- necessity to develop systems of engineering solutions on the basis of the methodological support of engineering design process;

- intensification of engineering studies, raising the level of detailed design engineering with accounting for distinctive features when efficient measuring and data processing procedures are applied;

- improved quality and complexity of building operations and processes, skill levels of technicians;

- increased scopes and importance of complex projects.

Working hypothesis. If we take into account the specific features and the impact of destabilizing factors on technical and economic indices of the process of instrumental determination of parameters of buildings with the aim to ensure their serviceability, it will allow us to optimize engineering processes at all stages of their life cycle. Thus, there is an opportunity to shorten building construction periods and prolong periods of building operation by implementing effective organizational and technological solutions that have been developed on the basis of data which have been obtained reliably and in proper time with the use of methods of instrumental measurements and which are necessary and sufficient for ensuring the serviceability of buildings and structures at all stages of their life cycles.

The scientific problem consists in a necessity of theoretical justification of a system of conceptual, theoretical and methodological principles of prolongation of the service life and optimization of engineering, technical and economic indices of construction and operation of buildings on the basis of application of efficient methods of instrumental measurements for collecting in proper time, processing and using reliable data that are necessary and sufficient for ensuring the serviceability of buildings at all stages of their life cycles. The application of information technologies will be favorable for solving this problem.

Selection of information technologies is an important component of a systemic approach to the issues of surveying, designing, construction, examination and diagnostics of building operating conditions. Such an approach is a necessity because the processes of determination, processing and application of data on parameter values of buildings, structures and 
developed areas require the use of developed interactive means of cooperation and support from experts with various levels of training in generation of information systems and models with the use of multiwindow models or screens, menu structures, dialog sequences etc. The data are collected from various sources and studied with various levels of detailing. The system capacity may be increased by applying an open architecture, and allowing the scaling of the system with connected both internal and external facilities, and arranging the modularity of applied programs, and supporting the flexibility of the required configuration of the system, and ensuring the use of open standards. Figures 1 and 2 show schemes of information technologies for an automated system and an algorithm of management information system for technical diagnostics of buildings.

\begin{tabular}{|c|c|c|}
\hline $\begin{array}{c}\text { Establishment of general } \\
\text { principles for generating a } \\
\text { diagnostics system of building } \\
\text { operating conditions at all stages } \\
\text { of life cycle }\end{array}$ & $\begin{array}{c}\text { Substantiation of efficiency of } \\
\text { technologies and means of } \\
\text { instrumental determination of } \\
\text { parameters of buildings, structures } \\
\text { and developed areas }\end{array}$ & $\begin{array}{l}\text { Selection of organizational and } \\
\text { technological indices for } \\
\text { calculation of efficiency of } \\
\text { measuring systems and } \\
\text { technology of their application }\end{array}$ \\
\hline $\begin{array}{c}\text { Establishment of necessary scopes } \\
\text { of instrumental examinations } \\
\text { during operation of buildings and } \\
\text { structures }\end{array}$ & $\begin{array}{l}\text { Determination of duration and } \\
\text { periodicity of instrumental } \\
\text { examinations as a component of } \\
\text { expenditures on operation of } \\
\text { measuring systems }\end{array}$ & $\begin{array}{l}\text { Effects of organizational and } \\
\text { technological indices on } \\
\text { efficiency of measuring systems } \\
\text { and technology of their } \\
\text { application }\end{array}$ \\
\hline $\begin{array}{c}\text { Substantiation of time } \\
\text { expenditures for execution of } \\
\text { measuring activities at all stages } \\
\text { of building life cycles }\end{array}$ & ANALYSIS OF UF & $\begin{array}{l}\text { INFORMATION } \\
\text { IES }\end{array}$ \\
\hline $\begin{array}{l}\text { Models and methods of creation } \\
\text { of a knowledge base for } \\
\text { diagnostics of building operating } \\
\text { conditions on the basis of the } \\
\text { theorv of fuzzy sets }\end{array}$ & $\begin{array}{l}\text { Experimental studies and } \\
\text { implementation of neural } \\
\text { networks of the diagnostics } \\
\text { system of building operating } \\
\text { conditions } \\
\end{array}$ & $\begin{array}{l}\text { Estimation procedure for } \\
\text { predictions of solutions made by } \\
\text { the diagnostics system of building } \\
\text { operating conditions }\end{array}$ \\
\hline
\end{tabular}

Fig. 1. Block scheme of up-to-date information technologies for an automated system of diagnostics of building operating conditions

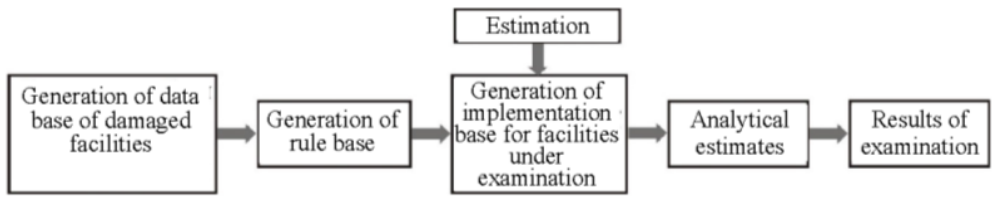

Fig. 2. Functional scheme of a management information systemfor diagnostics of building operating conditions 
The principle of designing of facilities with the use of their information models provides for the modelling process with preparation and complex processing of architectural and design, technological, economic and other data on a facility with all interrelations and dependencies in which a building and all related things are considered as a single facility ${ }^{2,3}$. This conception was named 'Building Information Modelling' or shortly BIM.

The main advantages of BIM are as follows: the whole project life cycle is simulated, from a conception until operation and demolition; in designing the facilities that possess necessary information about geometrical and technical characteristics of structures, elements and a building as a whole are used; the use of such facilities accelerates the design process and minimizes errors; sections generated by various systems of computer-aided design are used jointly and the design process is performed in 3D space with an allowance for time; an open standard of data exchange. Implementation of BIM is a strategic issue for the construction industry and its solving is an objective necessity ${ }^{4,5,6,7,8}$.

The building information model is a digital representation of systematic information about a facility that is used at all stages of life-cycle ${ }^{9,10}$. Application of an information model facilitates operations with a facility and offers significant benefits as compared with the traditional design methods $3,8,11,12,13,14,15,16,17,18,19,20,21,22,23$. Such a model allows unification,

2 Astaf'eva N.S., Kibireva Yu.A, Vasil'eva I.L. Advantages of application and difficulties of implementation of the building information modelling // Construction of unique buildings and structures. ISSN 2304-6295. 8 (59). 2017. P. 41-62 (in Russian).

3 Talapov V.V. Building information modelling - modern conception // CADmaster. 2010.No. P.114-121 (in Russian).

${ }^{4}$ Chikovskaia I.I. Implementation of BIM - experience, scenarios, mistakes, conclusions // SAPR and Graphics. 2013. No. 8. P. 18-22 (in Russian).

5 Krinitskii E.V., Yakubson V.M., Vatin N.I. Building information modelling (BIM) // Engineering and building journal 2010. No. 2(12). P. 16-18 (in Russian).

${ }^{6}$ Kozlov I.M. Estimation of economic efficiency of implementation of the building information modelling //AMIT. 2010. No. 1(10). P. 1-9 (in Russian).

${ }^{7}$ Demenev A.V., Artamanov A.C. Information modelling in the process of operation of buildings and structures // Sociology of science. 2015. No. 3. P. 1-9 (in Russian).

8 Talapov V.V. Technology of BIM. Essence and peculiarities of implementation of the building information modelling. M.:Publisher DMK Press, 2015. $410 \mathrm{p}$ (in Russian).

9 Vorob'ev A., Danilova L., Ignatov B., Ryndin A., Tuchkov A., Utkin A., Fertman I., Scheglov D. Scenario and mechanisms for developing a unified information space // CADmaster. 2010. No. 5. P. 48-51 (in Russian).

${ }^{10}$ Zamataev D.V. Study of approaches to virtual modelling // Mining information-analytical bulletin (scientific and engineering journal). 2014. No. 9. P. 312-316 (in Russian).

${ }^{11}$ Melikhov N.S., Kostiuchenko A.Yu., Yaschenko A.A., Narezhnaia T.K. Advantages of $\mathrm{BIM}$ in performing expert examination of design documentation // International scientific and research journal. 2016. No. 5-3. P. 143-145 (in Russian).

${ }^{12}$ Lushnikov A.S. Problems and advantages of implementation of BIM technologies in construction companies // Bulletin of civil engineers. 2015. No. 6. P. 252-256 (in Russian). 
calculation and coordination of components and systems developed by various specialists and institutions, checking their viability, serviceability and preventing internal mismatches and emergencies ${ }^{24}$.

Numerical data are used during a life cycle of facility for making project decisions, updating project documentation, predicting serviceability, drawing estimates and scheduling, ordering materials and equipment, managing construction work, operation, utilities commercial activities, reconstruction or repair work, if necessary, demolition and utilization of the facility, other tasks related to the facility ${ }^{6-12,25,26}$.

${ }^{13}$ Seliutina L.G., Timofeev S.V. Analysis of foreign experience of development and application of information modelling technologies in construction // Problems of construction economics and management under conditions of environmentally sensitive development. Tomsk: Publisher: Tomsk State Architectural and Construction University, 2015. P. 324-329 (in Russian).

${ }^{14}$ Perepelitsa F.A., Petukhova E.A. BIM standards in the world practice // Electronic scientific journal. 2015. No. 1(1). P. 561-566 (in Russian).

${ }^{15}$ Manukhina L.A., Yaschenko A.A. Integration of organizational and technological solutions with BIM // Innovation technologies in science and education. 2015. No. 2(2). P. 246-249 (in Russian).

${ }^{16}$ Talapov V.V. Principles of BIM: introduction into the building information modelling. M.: Publishers DMK Press, 2011. 392 p (in Russian).

${ }^{17}$ Ignatova E.V. Solving of problems on the basis of a building information model // Bulletin of MGSU. 2012. No. 9. P. 241-246 (in Russian).

${ }^{18}$ Talapov V.V. BIM in Russia: new building of Mariinskii Theatre [Electronic resource] URL: http://isicad.ru/ru/articles.php?article_num=14257 (date of visiting: 20.02.2016) (in Russian).

${ }^{19}$ Mitrofanova N.O., Chernov A.V., Berezina E.V. Possible applications of BIM technologies // Interexpo Geo-Siberia. 2016. No. 2. P. 177-182 (in Russian).

${ }^{20}$ Grakhov V.P., Mokhnachev S.A., Manokhin P.E., Ishtriakov A.Kh. Organizational improvements of design work by implementation of building information modelling technologies // Modern problems of science and education. 2015. No. 1-1. P. 615 (in Russian).

${ }^{21}$ El'sheikh A.M. Information modelling in integrated computer-aided designing and scheduling in construction [Place of thesis defence: Moscow State Building University]: abstract of thesis for a candidate degree in technical sciences: 05.13.12, 05.02.22 / A.M. El'sheikh. M., 2015. 21 p. (in Russian).

${ }^{22}$ Pailevanian B.S. Rising the level of environmental safety and energy consumption efficiency of buildings on the basis of intellectual technologies [Place of thesis defence: Moscow State Building University]: abstract of thesis for a candidate degree in technical sciences: 03.00.16 / B.S. Pailevanian. M., 2009. 23 p. (in Russian).

${ }^{23}$ Volynskov V.E. Information-technological methods of designing in architectural forming [Place of thesis defence: Moscow State Building University]: abstract of thesis for a candidate degree in architecture: 05.23.20 / V.E. Volynskov. - M., 2012. - 25 p. (in Russian).

${ }^{24}$ Alekseev S.A., Tyshkevich A.V., Alekseeva A.S., Chernykhovskii B.A. Urgency of implementation of the building information modelling in construction // Scientific discussion: issues of technical sciences. 2016. No. 1(31). P. 7-11 (in Russian).

${ }^{25}$ Talapov V.V. BIM is a basis // CADmaster. 2010. No. 4. P. 13 (in Russian).

${ }^{26}$ Morozov V.S., Ort A.I. Designing: from vocation to self-education // St. Petersburg: Construction, Technologies, Organization. 2014. No. P. 14-15 (in Russian). 
Unlike the traditional computer-aided design systems that generate geometrical images the result of information modelling is a digital model that includes as a facility itself as a process of its construction, operation and utilization $^{26,27,28,29,30,31,32,33,34,35}$. The US National Building Information Model Standard Project Committee has the following definition ${ }^{36,37}$ : 'BIM is a digital representation of physical and functional characteristics of a facility. A BIM is a shared knowledge resource for information during its life-cycle defined as existing from earliest conception to demolition, $38,39,40,41,42,43,44,45,46,47$.

${ }^{27}$ Malinovskii M.E. Information modelling technologies in design institutions // Anthology of world science. 2016. No. 4-1(7). P. 121-122 (in Russian).

${ }^{28}$ Panteleev A.S. Substantiation of effects exerted by investments on economic growth of enterprises in the construction industry of the North-West Federal Region of the RF [Place of thesis defence: Peter the Great SPbPU]: graduate thesis: 38.04.01: defended on 13.09.16: approved on 13.09.16 / Panteleev Alexander Sergeevich; Peter the Great SPbPU - SPb, 2016. 113 p. (in Russian).

${ }^{29}$ Postnov K.V. Application of BIM technologies for the management processes in design institutions // Scientific review. 2015. No. 18. P. 367-371 (in Russian).

${ }^{30}$ Bachurina S.S., Golosova T.S. Investment component in BIM implementation projects // Bulletin of MGSU. 2016. No. 2. P. 126-134 (in Russian).

${ }^{31}$ Del'tsova T.D., Afanas'eva T.V., Slepkova T.I. Efficiency of application of BIM technologies during reconstruction of facilities // Economy and Business. 2015. No. 6-3. P. 741-744 (in Russian).

${ }^{32}$ Rumiantseva E.V., Manukhina L.A. BIM technologies: an approach to designing a construction facility as a single whole // Modern science: urgent problems and ways of their solving. 2015. No. 5(18). P. 33-36 (in Russian).

${ }^{33}$ Chetverik N.P. Step-by-step implementation of information modelling technologies (BIM) in the construction sphere // Bulletin 2014 No. 12(191) P.44-47 (in Russian).

${ }^{34}$ Chernykh M.A., Yakushev N.M. BIM technology and program products on its basis in Russia // Bulletin. 2014. No. 1(61). P. 119-121 (in Russian).

${ }^{35}$ Talapov V.V. What does affect the implementation of BIM in Russia // SAPR and Graphics. 2010. No. 11(169). P. 12-16 (in Russian).

${ }^{36}$ Chikovskaia I.I., Novozhenina I.N. Trends in development of BIM in Russia. SAPR and Graphics. 2014. No. 8(214). P. 8-11 (in Russian).

${ }^{37}$ Eltyshev Yu.V., Kirillov A.I., Talapov V.V. BIM and metal structures: some examples // CAD-master. 2010. No. 4. P. 109-110 (in Russian).

${ }^{38}$ Baiburin A.Kh. Comprehensive estimation of quality of building operations / A.Kh. Baiburin // Bulletin of URGU. - 2005. - No. 13. - P. 68-70 (in Russian).

${ }^{39}$ Halins'kyi O. Arrangement of building production [Text]: DBN A.3.1-5:2016. [enforced from 2016-08-01] / O. Halins'kyi, P. Hryhorovskiy, A. Kotliarenko et al. - K.: Minregionbud of Ukraine, 2016. - 51 p. - (State building code of Ukraine) (in Ukrainian).

${ }^{40}$ Hryhorovskiy P.Ye. Method for determination of a compactness factor around a new construction facility / P.Ye. Hryhorovskiy, M.I. Nadtochii // Development management for complex systems: collection of scientific papers - K.: KNUBA. -2013 . - No. 16. - P. 181-183 (in Ukrainian).

${ }^{41}$ Hryhorovskiy P.Ye. Application of operating condition monitoring for buildings and structures for studying geodynamic and man-caused processes of their construction and operation / P.Ye. Hryhorovskiy, I.V. Trevoho, N.P. Chukanova // Geoinformation environmental monitoring: GNSS and GIS technologies: Proceedings of XXVIII International 
Diagnostics of building operation conditions may be performed with the use of information technologies: expert systems, fuzzy systems, fuzzy neural networks or hybrid networks, information storage and retrieval systems, intelligence decision-support systems and others shown in Fig. 3. Table 1 shows comparative characteristics of information technique methods.

Expert systems may be used for generation of expert models and models for diagnostics of building operating conditions, in studying information and expert systems, for generation of knowledge bases and fuzzy rules of studies in implementing management systems for examination and diagnostics of building operating conditions, for studies of logic chains in diagnostics of building operating conditions.

Expert systems are implemented and used in such program complexes as: Mycin, Neomycin, Emycin, Prospector, Diagen, Genrost, Internist-I, Sphinx, Pheo-attending (the medical expert systems), Exsys (designed for generation of expert systems of classification type), 1st-Class, Personal Consultant Plus, STES (software tools of expert systems), GURU (integrated environment for development of expert systems).

Scientific and Engineering Symposium. 10-15 September 2013. - Alushta, 2013. - P. 136-143 (in Ukrainian).

${ }^{42}$ Hryhorovskiy P.Ye. Selection of optimal methods for monitoring of building structures operating conditions with the use of utility functions / P.Ye. Hryhorovskiy, N.P. Chukanova // New technologies in construction: collection of scientific and engineering papers - K.: Publishers «Lira-K», 2014. - Issue. 27-28. - P. 21-24 (in Ukrainian).

${ }^{43}$ Hryhorovskiy P.Ye. Details of calculations of costs of labor for conducting survey operations in construction / P.Ye. Hryhorovskiy, N.P. Chukanova // Modern achievements of the land-surveying science and production: collection of scientific papers of the West Geodetic Society UTGK. - Lviv: Publishers Lviv Polytechnika, 2014. - Issue 1(27). - P. 148-151 (in Ukrainian).

${ }^{44}$ Hryhorovskiy P.Ye. Monitoring of building structures inclination with the use of an electronic plumb rule / P.Ye. Hryhorovskiy, Yu.V. Deineka, V.O. Kosolap // Building production: collection of scientific and technical papers - K.: TsP «Comprint», 2009. Issue. 50. - P. 8-10 (in Ukrainian).

${ }^{45}$ Hryhorovskiy P.Ye. Normative provisions for determination of estimated costs and labor intensities of construction work under restricted conditions / P.Ye. Hryhorovskiy, M.I. Nadtochii // Options for improvement of construction efficiency under conditions of formation of market relations: collection of scientific papers - K.: KNUBA - 2010. - No. 22. P. 87-93 (in Ukrainian).

${ }^{46}$ Hryhorovskiy P.Ye. Experience of conducting geodetic monitoring during reconstruction of the National Sports Complex 'Olimpiiskyi' / P.Ye. Hryhorovskiy, Yu.V. Deineka // New technologies in construction: collection of scientific and technical papers - K.: Publishers «LiraK», 2010. - Issue 19. - P. 18-20 (in Ukrainian).

${ }^{47}$ Hryhorovskiy P.Ye. Composition of knowledge base for an information expert system for selection of methods to be used during performance of survey operations in construction / P.Ye. Hryhorovskiy, Yu.V. Deineka, V.O. Kosolap // New technologies in construction: collection of scientific and technical papers - K.: Publishers «Lira-K», 2011. - Issue 21. P. 48-51 (in Ukrainian). 


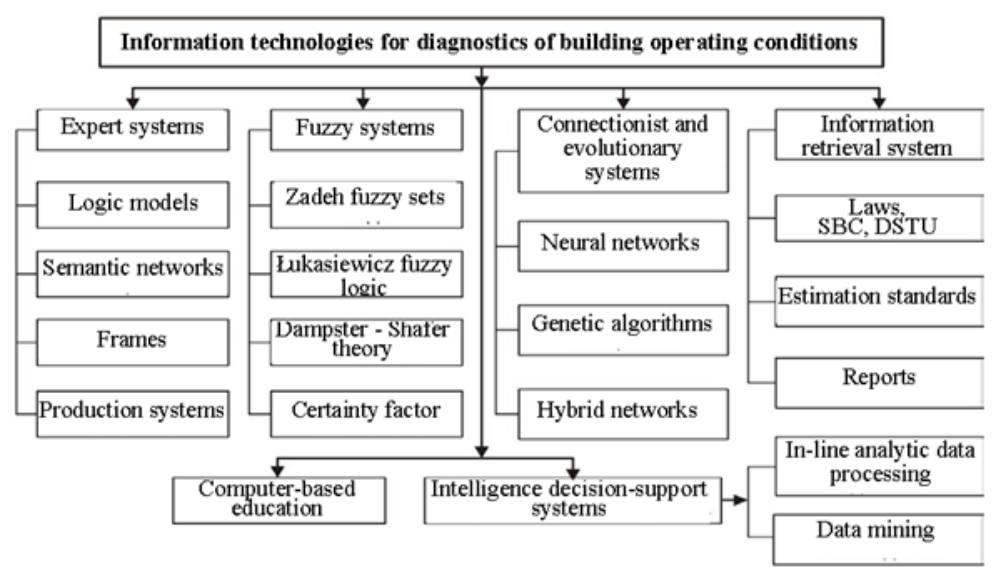

\section{Fig. 3. Block-scheme of building status information technologies}

Fuzzy systems may be used for solving information technology tasks such as diagnostics of building operating conditions, development of a knowledge bas for facilities, development of a fuzzy conclusion system, research into diagnostic models for building conditions on the basis of fuzzy logics techniques.

Fuzzy systems are implemented and used in such systems as $M O \check{S} / M I S$ (Mestská a Obecná Štatistika/Mestský Informačný Systém (Urban and municipal statistics / urban information system). They are used as an initial base for development a knowledge-based system. The «Systema - $P$ » system is a module of combined navigation satellite receiver (MCNR) that is designed for application in corporate integrated navigation and communication management and control systems. $C A D$ is a technique that combines a single complex for solving computer-aided designing tasks. $C A M$ is a process management system.

Fuzzy neural networks or hybrid networks combine benefits of neural networks and fuzzy inference systems. They provide for obtaining information about examinations of building operating conditions in the form of predictions, make it possible to use a training principle on the basis of available information for construction of neural networks, to develop system models in the form of fuzzy rules that are characterized by visibility and simple content interpretation. The fuzzy neural networks or hybrid networks are applied in the following systems: ANFIS (adaptive network-based fuzzy inference system) and RAISON (an integrated system based on knowledge, it comprises a neural network, data base, geoinformation system, cartographic analyzer, graphic and software language components). 


\section{Comparative characterization of methods of information technologies}

\begin{tabular}{|c|c|c|}
\hline Method & Benefits & \begin{tabular}{|c|} 
Shortcomings \\
\end{tabular} \\
\hline $\begin{array}{c}\text { Expert } \\
\text { systems }\end{array}$ & $\begin{array}{l}\text { Development of expert models for examination } \\
\text { and diagnostics of building operating conditions; } \\
\text { research into information and expert systems; } \\
\text { development a knowledge base and fuzzy rules; } \\
\text { research into chains of logic conclusions for } \\
\text { diagnostics of technical status. }\end{array}$ & $\begin{array}{l}\text { Complexity of representation of } \\
\text { expert's profound knowledge on } \\
\text { examination and diagnostics of } \\
\text { building operating conditions; } \\
\text { complexity of arrangement of } \\
\text { training on the basis of the } \\
\text { expert's experience. }\end{array}$ \\
\hline $\begin{array}{c}\text { Fuzzy } \\
\text { systems }\end{array}$ & $\begin{array}{l}\text { Development of a knowledge base for buildings, } \\
\text { development of a system of fuzzy deduction; } \\
\text { research and implementation of diagnostic } \\
\text { models for building operating conditions on the } \\
\text { basis of fuzzy logic tools. }\end{array}$ & $\begin{array}{l}\text { Subjectivity of examinations } \\
\text { and diagnostics of building } \\
\text { operating conditions; it doesn't } \\
\text { allow training. }\end{array}$ \\
\hline $\begin{array}{c}\text { Fuzzy } \\
\text { neural } \\
\text { networks or } \\
\text { hybrid } \\
\text { networks }\end{array}$ & $\begin{array}{l}\text { Possibility of obtaining information about } \\
\text { examination of buildings in the form of } \\
\text { prognosis; construction of neural networks for } \\
\text { examinations and diagnostics is performed by } \\
\text { their training on the basis of available and } \\
\text { accessible information; they allow development } \\
\text { and representation of system models as rules of } \\
\text { fuzzy productions that offer visualization and } \\
\text { simple interpretation of content. }\end{array}$ & $\begin{array}{l}\text { Representation of knowledge } \\
\text { about examinations and } \\
\text { diagnostics of building } \\
\text { operating conditions is obtained } \\
\text { in the special form that may } \\
\text { significantly differ from } \\
\text { possible content interpretation } \\
\text { of existing interrelations and } \\
\text { relations. }\end{array}$ \\
\hline $\begin{array}{l}\text { Genetic } \\
\text { algorithms }\end{array}$ & $\begin{array}{l}\text { In searching of an optimum a number of points } \\
\text { are checked simultaneously instead of passing } \\
\text { from one point to another and in this way local } \\
\text { optimums are excluded; no additional } \\
\text { information is required and this increases a } \\
\text { speed of algorithm operation; deterministic and } \\
\text { probable rules are used. }\end{array}$ & $\begin{array}{l}\text { Numeric not symbolic data are } \\
\text { used. }\end{array}$ \\
\hline $\begin{array}{l}\text { Information } \\
\text { storage and } \\
\text { retrieval } \\
\text { systems }\end{array}$ & $\begin{array}{l}\text { Availability of laws, normative documents, } \\
\text { estimation standards, state building code (SBD), } \\
\text { standards DSTU and others. }\end{array}$ & $\begin{array}{l}\text { Lack of an information system } \\
\text { that will ensure data processing } \\
\text { and selection of an optimal } \\
\text { technology subject to availability } \\
\text { of corresponding data bases in the } \\
\text { automatic mode. }\end{array}$ \\
\hline $\begin{array}{l}\text { Computer- } \\
\text { based } \\
\text { education }\end{array}$ & $\begin{array}{l}\text { Education tasks are solved on the basis either a } \\
\text { labyrinth model that provides for either a search } \\
\text { of direction of motion among the labyrinth of } \\
\text { possible variants or establishment of associative } \\
\text { links in neural-like structures }\end{array}$ & $\begin{array}{l}\text { Problems of generalization, } \\
\text { accumulation of skills in solving } \\
\text { tasks and application of such } \\
\text { problems in solving new tasks }\end{array}$ \\
\hline $\begin{array}{l}\text { Intelligence } \\
\text { decision- } \\
\text { support } \\
\text { systems }\end{array}$ & $\begin{array}{l}\text { The use of capabilities of building examination } \\
\text { information systems; contemporary data bases } \\
\text { comprise a number of technologies that improve } \\
\text { intellectual capabilities; intelligence information } \\
\text { systems for examination of facilities combine } \\
\text { the capabilities of DBMSs that are the basis of } \\
\text { information systems and as a result of this the } \\
\text { storage of information about examinations is } \\
\text { combined with data processing and preparation } \\
\text { for using in making decisions }\end{array}$ & $\begin{array}{l}\text { Complexity of representation of } \\
\text { various types of information }\end{array}$ \\
\hline
\end{tabular}

Genetic algorithms are applied for searching an optimum among some points simultaneously instead of using a point-by-point procedure. Such an 
approach excludes local optimums and the necessity of any additional information, increases operation of the algorithm. At that deterministic and probabilistic rules are used.

An information storage and retrieval system comprises legislative acts, normative documents, standards, registers of accident-prone facilities. The following may be considered as the information technology issues: construction and development of software, its adaptation for permanently evolving needs of users, fast and easy collection and review of information, keeping the status of actuality of the information, development and submission analytical summaries to users and others.

The intelligence decision-support system is a system for examination of operating conditions of construction facilities that combines capabilities of the data base management system, the basis of information systems. As a result the storage of data of examinations is combined with the operations of data processing and preparation to be used in decision making. The task of analysis is a search of hidden patterns, dependencies and interrelations which are useful in making decisions at various levels of the hierarchy. The intelligence decision-support systems are implemented and used in the following systems: OLAP (Discovery System and OLAP Affinity System) is designed for the intelligence analysis of many-dimensional aggregated data; the intelligence system $C A A P P$ is designed for supporting the process of making decisions in the tasks of designing and planning flexible systems.

\section{Instrumental measurements as a basis of automation of construction technological processes}

Modern methods of technologies, mechanization and automation of technological processes, project organization and management are interrelated and directed on attaining a common goal: reduction of terms and assurance of quality of construction work, extension of the life cycle duration of construction facilities. This goal may be attained by implementation of computer-aided systems of management, control and arrangement of technological processes with the use of information technologies and specialized software. In the construction industry operations are divided into the following types: mechanized, large-scale mechanized and automated.

In mechanized work (Fig. 4-a) the main operations are performed with the use of machines, equipment, plants and tools which have mechanical, electric, pneumatic, hydraulic or combined drives. During large-scale mechanized work all labor-intensive operations and processes are mechanized. Machines, equipment and other technological means are interrelated with productivity and provide for the rate of work set by a leading machine. 
Computer-aided processes are divided into partial, comprehensive and complete automation processes.

The partial automation provides for application of automated equipment, instruments and devices during some, mainly basic production operations. The most part of building machines and equipment are fitted up with such instruments and devices.

The large-scale automation provides for application of a system of some units, machines, instruments and devices which are combined as a single process line and perform all operations of a production process. At that the operator performs only the start and stop operations; the set parameters of the production process are maintained automatically at all its stages.
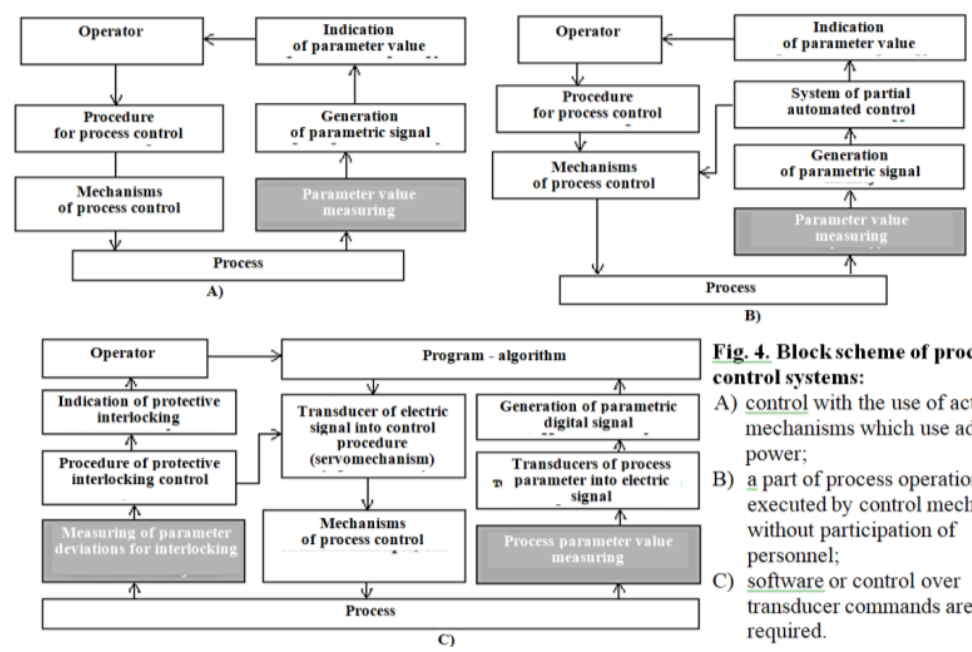

Fig. 4. Block scheme of process control systems:

A) control with the use of actuating mechanisms which use additional power;

B) a part of process operations is executed by control mechanisms without participation of personnel;

C) software or control over transducer commands are required.

The complete automation ensures fulfillment not only all basic but also auxiliary production operations as well as conduction of automatic control and process monitoring including changes in parameters and types of products in accordance with a specified program.

Means of automation are divided into controlling, protecting, regulating and monitoring devices. A process automation system provides for utilization of various combinations of the above types of devices. Control functions may be divided into non-automatic, automated and automatic ones according to a degree of participation of a person in them. The non-automatic process control may be manual or mechanized. Under manual control a person determines the required control actions on his (her) own, performs and checks them visually or by indications of elementary instruments. Under mechanized process control 
(Fig. 4, A) actuating mechanisms that consume additional energy (electrical, compressed air or working fluid etc.) are used. At that the instruments via corresponding transducers only inform the operator about process disturbances.

Under automated control (Fig. 4, B) a part of process operations is performed by control mechanisms without participation of any person. In this case the transducer signals of process disturbances are received not only by alarm devices but also by servomechanisms. The latter affect the control mechanisms on their own. They can stop actions of tools or the whole machine. The remained working functions of the operator are trouble-shooting, machine restarting and others.

The automatic control (Fig. 4, B) provides for control over transducers or software commands. This system comprises two basic parts: controlling and monitoring. Under such a control system a person is only engaged in preliminary installation of a certain program (algorithm), trouble-shooting in accordance with the transducers' signals (adjustment and repair of mechanisms) and starting the machine into operation or its turning off. At that a person only inserts a code of a required control program for obtaining the required result. Processes are controlled with the use of an automatic control system (ACS) that is an assembly of a facility under control and control device that interact without participation of any person.

According to the block schemes of the process control systems shown in Figure 4 the procedure of any type of automated process consisted of operations of obtaining and processing data, making and implementing process control decisions includes elements that provide for instrumental measurements and processing of the data related to a process parameter under control.

Therefore the reduction of terms of construction work and the extension of terms of building operation is an urgent technical and economic issue that will require effective solutions at all stages of the life cycle such as survey and design work, preparation work, earthwork, construction of ground structures, operation, period of deterioration and life cycle termination or beginning a new life cycle subject to renovation of facility serviceability.

The scientific problem is a necessity of theoretical substantiation of extension of the terms of operation and reduction of the terms of construction work for account of the effective automatic control over organizational and technological processes with the use of basic data obtained by the methods of instrumental measurements at all stages of the life cycle of building facilities. The scientific substantiation and development of methodological principles of generation of organizational and technological solutions of automatic process control with the use of basic data obtained by methods of instrumental measurements at all stages of the life cycle of building facilities are objects of further studies. 
Objects of studies are organizational and technological solutions of automatic control over organizational and technological processes with the use of building information models and data obtained by instrumental methods and measurement means, independent or integrated into the automatic control system.

Subjects of studies are parameters of organizational, technological and technical solutions of automatic control over organizational and technological processes with the use of building information models and data obtained by instrumental methods and means of measurements, independent or integrated into the automatic control system.

The scientific conception consists in a possibility of reduction of the terms of construction work and extension of the terms of operation of buildings and structures for account of implementation of effective organizational and technological as well as engineering solutions of automatic process control issues with the use of building information models and data obtained by methods of instrumental measurements at all stages of the life cycle.

Thereby the development of integrated models and methods for the system of automated diagnostics of building facility operating conditions is a major step for establishment of an integrated automated system that will ensure the serviceability of buildings and structures at all stages of their life cycles.

\section{Research into mechanisms of influence of technologies and organization of measuring work on duration of building life cycles}

In the process of research into mechanisms of influence of technologies and organization of measuring work on life cycle duration of building facilities it has been established that the building life cycle duration may be increased when risks of emergencies are timely detected and the corresponding measures are taken in proper time. Prediction of the longevity parameter is based on estimations of probabilistic-statistical models with the use of data of instrumental examinations of states of structures.

It has been revealed that the building life cycle duration is affected by general factors, as well as engineering and performance factors. In the long run building depreciation is aggravated nevertheless it may be less intensive if the results of instrumental examinations are used and the building serviceability is maintained for account of repair and rehabilitation work. Untimely execution of such work results in an increase of expenditures on restoring of necessary service characteristics and emergencies in a case of an ungrounded increase in the period between overhauls (Fig. 5). 


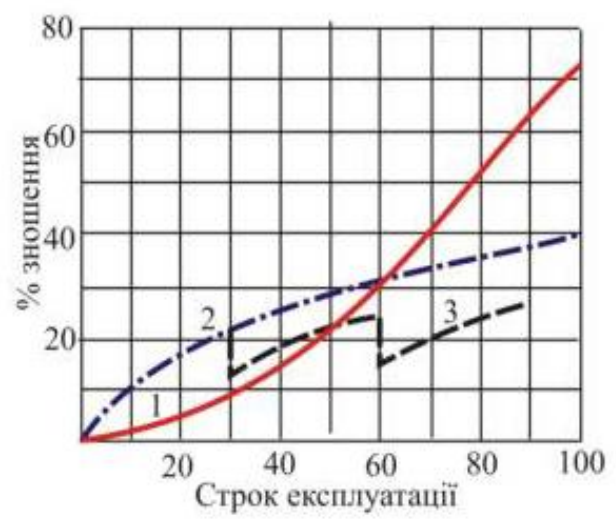

Fig. 5. Depreciation vs. building operating time:

1 - theoretical curve; 2 - actual data in a case of scheduled repairs;

3 - in a case of timely repair and rehabilitation work

During the life-cycle a set of measures for acquisition of information that is required for execution of work of the corresponding stage is implemented. The volume of this information defines the soundness of decisions made for maintaining facilities' performances at the required level. The developed topology of methods of instrumental measurements at the corresponding stages of construction and operation of facilities is presented in Fig. 6. It shows that at the construction stage the measuring operations are performed simultaneously or sequentially with the construction operations.

When the efficiency of available measuring operations is evaluated the possibility of making allowances for all factors is not obvious as the affecting factors are fuzzy and the decisions to be made depend on technological, technical or metrological parameters, subjectivity of solutions chosen by work performers, natural factors. The variants of measuring operations to be performed, the factors affecting the selection of measuring methods to be used, the degree of relevancy and influence of factors in a particular variant are determined with the use of the method of expert estimations.

It has been established that the issue of selection of means and methods of instrumental measurements should be considered not only with allowance for accuracy but also with consideration of minimum terms, costs and quality of construction and measuring work to be 
performed. At that, the arrangement and technology of work may be designed in such a manner that irrespective of the scope of time spent on measuring operations the reduction of time spent on fulfillment of construction processes will be significant. The main risks of failures may occur during manufacturing of elements and structures, installation of structures, in the initial period of operation of buildings or during next stages. Theses risks may be a result of negative effects of loads and unforeseen factors including drawbacks of the system of operation, unjustified replacements of structural elements (Fig. 7).

A scheme of substantiation of efficiency of means and technologies of instrumental measurements of building parameters at all stages of the building life cycle on the basis of comparison of organizational and technological indices classified by their importance has been proposed. The basic indices are of general character. They characterize the efficiency criterion to the utmost when are used together with other indices. Such additional indices are applied in such cases when the effects of specific factors of the corresponding stages of the life cycle shall be additionally accounted for. The method for determination of work productivity for different variants of organization and technology, means and methods of measurements with allowance for organizational, technological and technical factors provides for establishment of three categories of productivity: design-estimated, technical and operating.

Interrelations and interference of measuring operations and the basic engineering processes are of principal importance. They are a cause of increased labor costs for both measuring and basic processes unless they are sufficiently substantiated (organizationally and technologically) in the design and operation documentation. It has been established that the organizational and technological conditions for execution of measuring operations depend on a stage of the facility life cycle and determine approaches to justification of time expenditures for such work. 


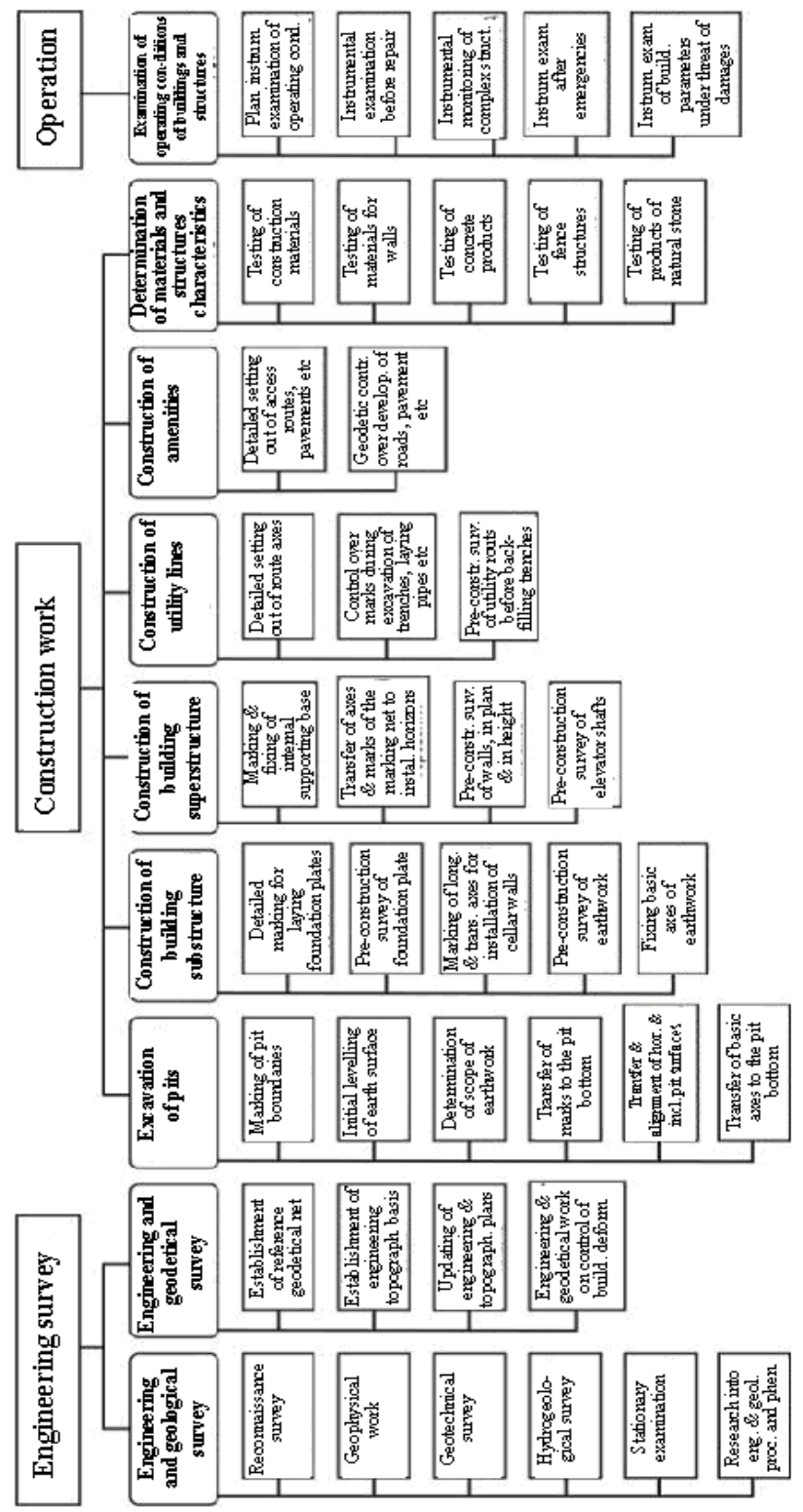

Fig. 6. Topology of instrumental measurement methods during construction and operation of building facilities 


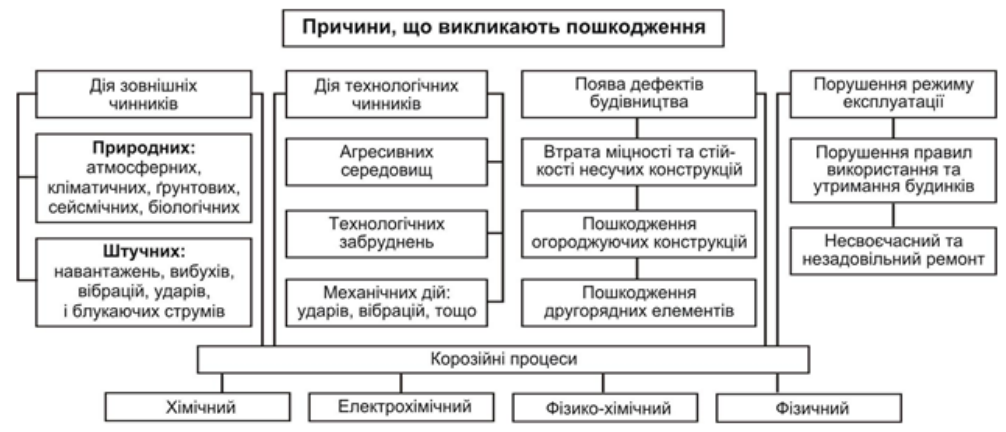

Fig. 7. Causes of occurrence of damages in buildings

Figure 8 shows a developed scheme of the method for substantiation of efficiency of measuring systems with the use of models and procedures of provision of building serviceability. The method is based on an algorithmic simulation of comprehensive processes used for determination of parameters of buildings, structures and development areas by instrumental methods together with some optimization parametric models for improving the efficiency of measuring work. Such an approach allows us to enlarge structurally and consolidate the performed parametric optimization. The mathematical model of linear dynamic system may be composed on the basis of mathematical models of elements and sections which form the system. Generally, the linear system includes sections that are joined sequentially or in parallel, surrounded by back or cross-back links. A block scheme of implementation of the comprehensive process of provision of serviceability and safety of buildings at all stages of the life cycle has been developed.

Combined modelling of the comprehensive process of measuring operations and some optimization parametric models for improving their efficiency provides for application of models and methods of determination of organizational and technological indices, establishment of a system for estimation and diagnostics of building operating conditions at all stages of the life cycle for development of recommendations on organization and process of parameter determination for buildings, structures and development areas in the design, engineering and operation documentation.

The recommendations on organization and process of parameter determination for buildings, structures and development areas for application in the design, engineering and operation documentation have been developed and included in the current normative documents. 
Аналіз та вибір етапів життєого циклу для впровадження системи будівельно-виміювальних робіт

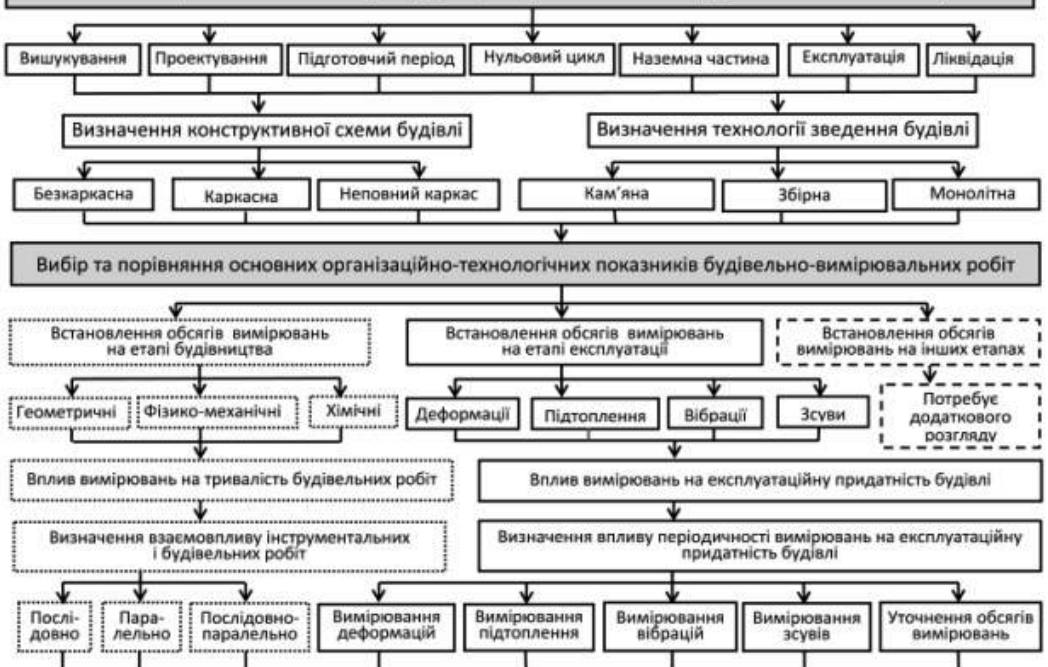

Вибір та порівняння додаткових організаційно-технічних показників будівельно-вимірювальних робіт

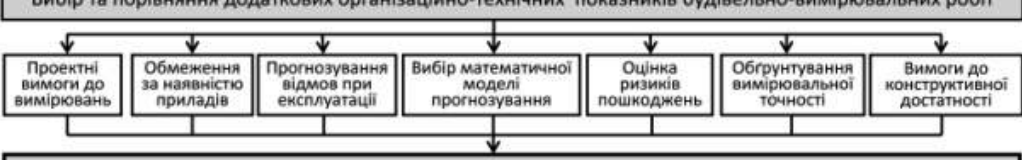

Визначення витрат часу та трудовитрат будівельно-вимірювальних робіт, з врахуванням чинників впливу.
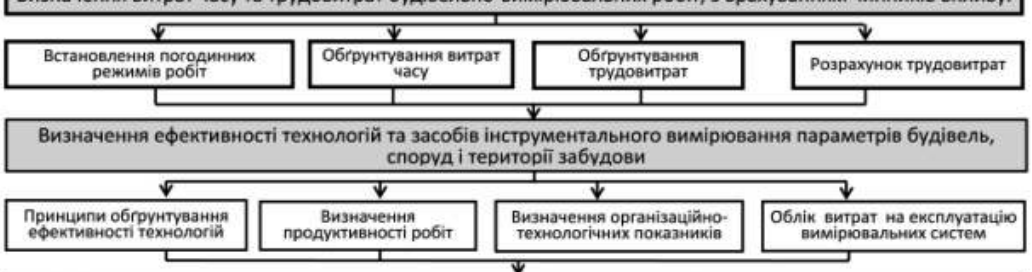

Порівняння та вибір вимірювальних систем 3 використанням моделей і методів формування системи експлуатаційної придатності будівель

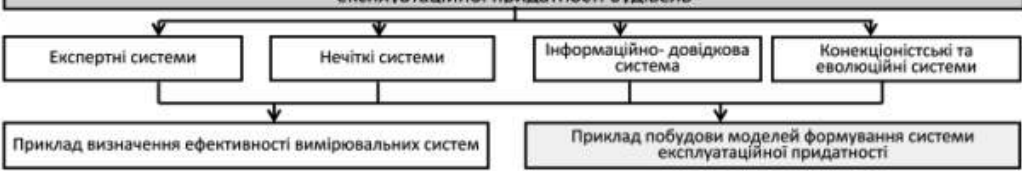

Fig. 8. Block scheme of modelling a comprehensive process of determination of serviceability at all stages of the building life cycle 


\section{CONCLUSIONS}

Modern methods of technologies, mechanization and automation of technological processes, project organization and management are interrelated and directed on attaining a common goal: reduction of terms and assurance of quality of construction work, extension of the life cycle duration of construction facilities.

This goal may be attained by implementation of effective organizational and technological as well as technical solutions for automated control of processes with the use of building information models and technologies, and information obtained by methods of instrumental measurements at all stages of the life cycle.

In this connection the development of integrated models and methods of automated system of diagnostics of building facilities operating conditions is one of the basic stages of designing a comprehensive automated system for ensuring the serviceability of buildings and structures at all stages of their life cycles.

Irrespective of a type of automated process the chain consisted of operations of data acquisition and processing, making and implementing decisions on controlling processes also comprises instrumental measurements and processing of data related to values of the technical parameter under control.

Automated process control and management systems may be developed on the basis of systems of instrumental monitoring of building serviceability at all stages of the life cycle. An automated monitoring system is a basis of any system designed for process controlling at all stages of the life cycle.

Such a system shall account for factors of influence on serviceability of buildings. The basic and additional performance indices account for economic, technical, technological and organizational factors of influence on the efficiency of automated systems.

\section{SUMMARY}

Methods of technologies, mechanization and automation of technological processes, project organization and management are interrelated and directed on attaining a common goal: reduction of terms and assurance of quality of construction work, extension of the life cycle duration of construction facilities, for account of organizational and technological as well as technical solutions for automated control of processes with the use of building information models and technologies, and information obtained by methods of instrumental measurements at all stages of the life cycle. The development of integrated models and methods of automated system of diagnostics of building facilities operating conditions is an initial stage of designing a comprehensive automated system for ensuring the serviceability 
of buildings. The automated system comprises integrated components for instrumental measurements and data processing. Therefore the measurements are the basis for automation of processes at all stages of the building life cycle.

\section{REFERENCES}

1 Havryliak A.I. Operation, reconstruction and modernization of buildings / A. I. Havryliak, I. B. Bazarnyk, R. I. Kinash et al. - L'viv: Publisher National University «L'vivska politekhnika», 2006. - 537 p. (in Ukrainian).

2 Astaf'eva N.S., Kibireva Yu.A, Vasil'eva I.L. Advantages of application and difficulties of implementation of the building information modelling // Construction of unique buildings and structures. ISSN 2304-6295. 8 (59). 2017. P. 41-62 (in Russian).

3 Talapov V.V. Building information modelling - modern conception // CADmaster. 2010. No. P. 114-121 (in Russian).

4 Chikovskaia I.I. Implementation of BIM - experience, scenarios, mistakes, conclusions // SAPR and Graphics. 2013. No. 8. P. 18-22 (in Russian).

5 Krinitskii E.V., Yakubson V.M., Vatin N.I. Building information modelling (BIM) // Engineering and building journal 2010. No. 2(12). P. 16-18 (in Russian).

6 Kozlov I.M. Estimation of economic efficiency of implementation of the building information modelling //AMIT. 2010. No. 1(10). P. 1-9 (in Russian).

7 Demenev A.V., Artamanov A.C. Information modelling in the process of operation of buildings and structures // Sociology of science. 2015. No. 3. P. 1-9 (in Russian).

8 Talapov V.V. Technology of BIM. Essence and peculiarities of implementation of the building information modelling. M.: Publisher DMK Press, 2015. $410 \mathrm{p}$ (in Russian).

9 Vorob'ev A., Danilova L., Ignatov B., Ryndin A., Tuchkov A., Utkin A., Fertman I., Scheglov D. Scenario and mechanisms for developing a unified information space // CADmaster. 2010. No. 5. P. 48-51 (in Russian).

10 Zamataev D.V. Study of approaches to virtual modelling // Mining information-analytical bulletin (scientific and engineering journal). 2014. No. 9. P. 312-316. (in Russian).

11 Melikhov N.S., Kostiuchenko A.Yu., Yaschenko A.A., Narezhnaia T.K. Advantages of BIM in performing expert examination of design documentation // International scientific and research journal. 2016. No. 5-3. P. 143-145 (in Russian). 
12 Lushnikov A.S. Problems and advantages of implementation of BIM technologies in construction companies // Bulletin of civil engineers. 2015. No. 6. P. 252-256 (in Russian).

13 Seliutina L.G., Timofeev S.V. Analysis of foreign experience of development and application of information modelling technologies in construction // Problems of construction economics and management under conditions of environmentally sensitive development. Tomsk: Publisher: Tomsk State Architectural and Construction University, 2015. P. 324-329 (in Russian).

14 Perepelitsa F.A., Petukhova E.A. BIM standards in the world practice // Electronic scientific journal. 2015. No. 1(1). P. 561-566 (in Russian).

15 Manukhina L.A., Yaschenko A.A. Integration of organizational and technological solutions with BIM // Innovation technologies in science and education. 2015.No. 2(2). P. 246-249 (in Russian).

16 Talapov V.V. Principles of BIM: introduction into the building information modelling. M.: Publishers DMK Press, 2011. 392 p. (in Russian).

17 Ignatova E.V. Solving of problems on the basis of a building information model // Bulletin of MGSU. 2012. No. 9. P. 241-246 (in Russian).

18 Talapov V.V. BIM in Russia: new building of Mariinskii Theatre [Electronic resource] URL: http://isicad.ru/ru/articles.php?article_num= 14257 (date of visiting: 20.02.2016) (in Russian).

19 Mitrofanova N.O., Chernov A.V., Berezina E.V. Possible applications of BIM technologies // Interexpo Geo-Siberia. 2016. No. 2. P. 177-182 (in Russian).

20 Grakhov V.P., Mokhnachev S.A., Manokhin P.E., Ishtriakov A.Kh. Organizational improvements of design work by implementation of building information modelling technologies // Modern problems of science and education. 2015. No. 1-1. P. 615 (in Russian).

21 El'sheikh A.M. Information modelling in integrated computer-aided designing and scheduling in construction [Place of thesis defence: Moscow State Building University]: abstract of thesis for a candidate degree in technical sciences: 05.13.12, 05.02.22 / A.M. El'sheikh. M., 2015. 21 p. (in Russian).

22 Pailevanian B.S. Rising the level of environmental safety and energy consumption efficiency of buildings on the basis of intellectual technologies [Place of thesis defence: Moscow State Building University]: abstract of thesis for a candidate degree in technical sciences: 03.00.16 / B.S. Pailevanian. M., 2009. 23 p. (in Russian). 
23 Volynskov V.E. Information-technological methods of designing in architectural forming [Place of thesis defence: Moscow State Building University]: abstract of thesis for a candidate degree in architecture: 05.23.20 / V.E. Volynskov. - M., 2012. - 25 p. (in Russian).

24 Alekseev S.A., Tyshkevich A.V., Alekseeva A.S., Chernykhovskii B.A. Urgency of implementation of the building information modelling in construction // Scientific discussion: issues of technical sciences. 2016. No. 1(31). P. 7-11 (in Russian).

25 Talapov V.V. BIM is a basis // CADmaster. 2010. No. 4. P. 13 (in Russian).

26 Morozov V.S., Ort A.I. Designing: from vocation to self-education // St. Petersburg: Construction, Technologies, Organization. 2014. No. P. 14-15 (in Russian).

27 Malinovskii M.E. Information modelling technologies in design institutions // Anthology of world science. 2016. No. 4-1(7). P. 121-122 (in Russian).

28 Panteleev A.S. Substantiation of effects exerted by investments on economic growth of enterprises in the construction industry of the NorthWest Federal Region of the RF [Place of thesis defence: Peter the Great SPbPU]: graduate thesis: 38.04.01: defended on 13.09.16: approved on 13.09.16 / Panteleev Alexander Sergeevich; Peter the Great SPbPU - SPb, 2016. 113 p. (in Russian).

29 Postnov K.V. Application of BIM technologies for the management processes in design institutions // Scientific review. 2015. No. 18. P. 367-371 (in Russian).

30 Bachurina S.S., Golosova T.S. Investment component in BIM implementation projects // Bulletin of MGSU. 2016. No. 2. P. 126-134 (in Russian).

31 Del'tsova T.D., Afanas'eva T.V., Slepkova T.I. Efficiency of application of BIM technologies during reconstruction of facilities // Economy and Business. 2015. No. 6-3. P. 741-744 (in Russian).

32 Rumiantseva E.V., Manukhina L.A. BIM technologies: an approach to designing a construction facility as a single whole // Modern science: urgent problems and ways of their solving. 2015. No. 5(18). P. 33-36 (in Russian).

33 Chetverik N.P. Step-by-step implementation of information modelling technologies (BIM) in the construction sphere // Bulletin 2014 No. 12(191) P. 44-47 (in Russian).

34 Chernykh M.A., Yakushev N.M. BIM technology and program products on its basis in Russia // Bulletin. 2014. No. 1(61). P. 119-121 (in Russian). 
35 Talapov V.V. What does affect the implementation of BIM in Russia // SAPR and Graphics. 2010. No. 11(169). P. 12-16 (in Russian).

36 Chikovskaia I.I., Novozhenina I.N. Trends in development of BIM in Russia. SAPR and Graphics. 2014. No. 8(214). P. 8-11 (in Russian).

37 Eltyshev Yu.V., Kirillov A.I., Talapov V.V. BIM and metal structures: some examples // CAD-master. 2010. No. 4. P. 109-110 (in Russian).

38 Baiburin A.Kh. Comprehensive estimation of quality of building operations / A.Kh. Baiburin // Bulletin of URGU. - 2005. - No. 13. P. 68-70 (in Russian).

39 Halins'kyi O. Arrangement of building production [Text]: DBN A.3.1-5:2016. - [enforced from 2016-08-01] / O. Halins'kyi, P. Hryhorovskiy, A. Kotliarenko et al. - K.: Minregionbud of Ukraine, 2016. - 51 p. - (State building code of Ukraine) (in Ukrainian).

40 Hryhorovskiy P.Ye. Method for determination of a compactness factor around a new construction facility / P.Ye. Hryhorovskiy, M.I. Nadtochii // Development management for complex systems: collection of scientific papers - K.: KNUBA. - 2013. - No. 16. - P. 181-183 (in Ukrainian).

41 Hryhorovskiy P.Ye. Application of operating condition monitoring for buildings and structures for studying geodynamic and man-caused processes of their construction and operation / P.Ye. Hryhorovskiy, I.V. Trevoho, N.P. Chukanova // Geoinformation environmental monitoring: GNSS and GIS technologies: Proceedings of XXVIII International Scientific and Engineering Symposium. 10-15 September 2013. - Alushta, 2013. P. 136-143 (in Ukrainian).

42 Hryhorovskiy P.Ye. Selection of optimal methods for monitoring of building structures operating conditions with the use of utility functions / P.Ye. Hryhorovskiy, N.P. Chukanova // New technologies in construction: collection of scientific and engineering papers $-\mathrm{K}$.: Publishers «Lira-K», 2014. - Issue. 27-28. - P. 21-24 (in Ukrainian).

43 Hryhorovskiy P.Ye. Details of calculations of costs of labor for conducting survey operations in construction / P.Ye. Hryhorovskiy, N.P. Chukanova // Modern achievements of the land-surveying science and production: collection of scientific papers of the West Geodetic Society UTGK. - L'viv: Publishers L'viv Polytechnika, 2014. - Issue 1(27). P. 148-151 (in Ukrainian).

44 Hryhorovskiy P.Ye. Monitoring of building structures inclination with the use of an electronic plumb rule / P.Ye. Hryhorovskiy, Yu.V. Deineka, V.O. Kosolap // Building production: collection of scientific and technical papers - K.: TsP «Comprint», 2009. - Issue. 50. - P. 8-10 (in Ukrainian). 
45 Hryhorovskiy P.Ye. Normative provisions for determination of estimated costs and labor intensities of construction work under restricted conditions / P.Ye. Hryhorovskiy, M.I. Nadtochii // Options for improvement of construction efficiency under conditions of formation of market relations: collection of scientific papers - K.: KNUBA - 2010. - No. 22. - P. 87-93 (in Ukrainian).

46 Hryhorovskiy P.Ye. Experience of conducting geodetic monitoring during reconstruction of the National Sports Complex 'Olimpiiskyi' / P.Ye. Hryhorovskiy, Yu.V. Deineka // New technologies in construction: collection of scientific and technical papers - K.: Publishers «Lira-K», 2010. - Issue 19. - P. 18-20 (in Ukrainian).

47 Hryhorovskiy P.Ye. Composition of knowledge base for an information expert system for selection of methods to be used during performance of survey operations in construction / P.Ye. Hryhorovskiy, Yu.V. Deineka, V.O. Kosolap // New technologies in construction: collection of scientific and technical papers - K.: Publishers «Lira-K», 2011. - Issue 21. - P. 48-51 (in Ukrainian).

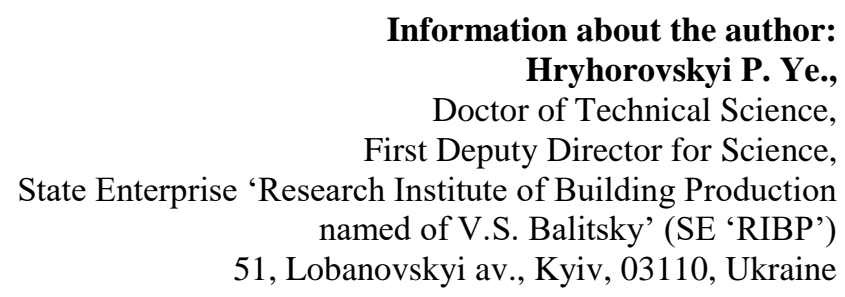

